\begin{tabular}{|c|c|}
\hline & $\begin{array}{r}\text { ABSYARA: Jurnal Pengabdian Pada Masyarakat } \\
\text { Vol. 1, No. 2, Desember } 2020 \\
\text { Hal. 35-42 }\end{array}$ \\
\hline 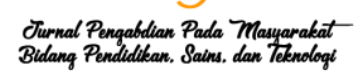 & e-ISSN: $2723-6269$ \\
\hline
\end{tabular}

\title{
Edukasi Zero Waste Berbasis Teknologi Informasi
}

\author{
Rasyid Hardi Wirasasmita ${ }^{1}$, Baiq Desi Dwi Arianti ${ }^{2}$, Muhammad Zamroni Uska ${ }^{3}$, \\ Yosi Nur Kholisho ${ }^{4}$, Zoatul Wardi ${ }^{5}$

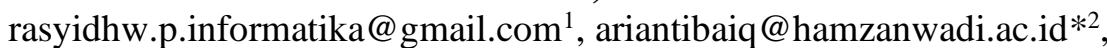 \\ zamroni_uska@hamzanwadi.ac.id ${ }^{3}$, yosink.peninfo@gmail.com ${ }^{4}$, zaowardi@hamzanwadi.ac.id ${ }^{5}$ \\ 1,2,3,4Program Studi Pendidikan Informatika, Universitas Hamzanwadi \\ ${ }^{5}$ Program Studi Pendidikan Matematika, Universitas Hamzanwadi
}

Received: 12 November 2020 Accepted: 25 Desember $2020 \quad$ Online Published: 31 Desember 2020 DOI: 10.29408/ab.v1i2.2749 URL: http://dx.doi.org/10.29408/ab.v1i2.2749

\begin{abstract}
Abstrak: Program Pengabdian Pada Masyarakat (PPM) ini bertujuan untuk mensosialisasikan program lingkungan Zero Waste (ZW) dan melatih masyarakat untuk mengelola sampah (barang bekas) menjadi barang yang bisa dimanfaatkan (daur ulang) menggunakan aplikasi berbasis android. Metode yang digunakan yaitu ceramah dan demonstrasi (pelatihan secara langsung). Untuk edukasi program lingkungan Zero Waste yaitu melalui penggunaan aplikasi Zero Waste yang telah dikembangkan sebelumnya, sedangkan untuk pelatihan pemanfaatan sampah menjadi barang yang lebih bermanfaat, dilakukan melalui demonstrasi atau pelatihan secara langsung (praktik). Tempat pelaksanaan pengabdian pada masyarakat ini yaitu di Dusun Lengkok Lendang, Desa Tembeng Putik, Kabupaten Lombok Timur, Nusa Tenggara Barat (NTB). Selama ini di Tembeng Putik belum pernah diadakan pelatihan tentang pengolahan sampah dan lingkung Zero Waste, sehingga pengetahuan dan kesadaran masyarakat tentang kesehatan lingkungan masih rendah. Hasil yang didapat yaitu terbentuknya pengetahuan masyarakat tentang pentingnya lingkungan Zero Waste dan masyarakat mampu untuk membuat atau mengelola sampah menjadi barang jadi yang lebih bermanfaat.
\end{abstract}

Kata Kunci: Edukasi; Teknologi Informasi; Zero Waste

\begin{abstract}
This Community Service program aims to socialize the Zero Waste (ZW) environmental program and to train the community to manage waste (used goods) into goods that can be recycled using an Android-based application. The methods used are lectured and demonstrations (hands-on training). For education on the Zero Waste environmental program through the Zero Waste application, training through demonstrations or direct training (practice). The location for implementing this community service is in Lengkok Lendang hamlet, Tembeng Putik village, East Lombok regency, Nusa Tenggara Barat (NTB) province. So far, at Tembeng Putik, there has never been any training on Waste Management and the Zero Waste environment program, so that public knowledge and awareness about environmental health are still low. The results obtained are the formation of this knowledge about the Zero Waste environment's importance, and the community can make or manage waste into more valuable finished goods.
\end{abstract}

Keyword: Education; Information Technology; Zero Waste;

\section{PENDAHULUAN}

Kepedulian terhadap lingkungan merupakan hal mendasar dalam mendorong kesadaran seseorang terhadap lingkungan yang ada di sekitarnya. Kesadaran tersebut bisa berbentuk mengupayakan tindakan untuk menjaga lingkungan, mencintai kebersihan, serta lebih bijak dalam mengelola dan memanfaatkan segala hal yang ada di lingkungan. Manusia sebagai makhluk berpikir harus mampu memanfaatkan segala hal yang ada dilingkungan, terutama dalam mengelola sampah dengan baik. Undang-undang Republik Indonesia Nomor 18 Tahun 2008 tentang pengolahan sampah menyatakan bahwa pertambahan penduduk dan pola 
konsumsi berpengaruh pada pertambahan volume, jenis, dan karakteristik sampah yang semakin beragam. Selain itu berdasarkan Peraturan Gubernur nomor 44 tahun 2019 pasal 3 nomor 3 salah satu program unggulan yang dicanangkan oleh pemerintah daerah NTB adalah tentang Gemilang Lingkungan salah satunya mengenai zero waste. Berdasarkan data Badan Pusat Statistik (BPS) bahwa sampah yang dihasilkan meningkat tiap tahunnya, di mana tahun 2019 meningkat sebesar 67,1 juta ton dibandingkan tahun 2018 (Zulkifli, Ayud, Shery, 2019).

Rendahnya kesadaran dan kepedulian masyarakat terhadap sampah serta ketersediaan lahan TPA (Tempat Pembuangan Akhir) yang tidak memadai, sehingga sampah tidak tertangani dengan baik mendorong harus dilakukannya upaya penanganan alternative untuk menuntaskan permasalahan sampah. Lingkungan yang bersih dan sehat dapat digalangkan dengan pemanfaatan dan pengelolaan sampah dengan baik dan benar melalui kegaiatan edukasi zero waste di NTB khususnya di Kabupaten LomboK Timur.

Zero waste merupakan konsep pengolahan sampah yang didasarkan pada kegiatan daur ulang. Konsep dalam menangani sampah dengan sistematis akan mengurangi jumlah untuk melestarikan dan memulihkan sumber daya lingkungan, sehingga sampah dari hasil kegiatan masyarakat akan tertangani dengan baik seperti pembuatan bunga dari bekas plastik, kompos dari sampah organik, tas dari bungkus kopi saset dan sebagainya. Berdasarkan pendapat di atas bahwa untuk memudahkan masayarkat belajar akan pentingnya lingkungan yang zero waste sehingga dikembangkan aplikasi edukasi zero waste dengan tujuan dapat mempermudah masyarakat mendapatkan edukasi terkait zero waste, selain itu adanya pelatihan - pelatihan pemanfaatan sampah plastik menjadi hasil karya yang dapat bermanfaat bagi masyarakat (Widiarti, 2012).

Keberhasilan program zero waste tidak lepas dari rasa sadar masyarakat mencintai lingkungan mereka sendiri dan oleh sebab itu perlu adanya media untuk mendorong rasa sadar masyarakat dan memperoleh pengetahuan mengenai pengolahan sampah bernialai ekonomis, sehingga terciptanya budaya zero waste (Intan, Rijati, 2019). Dengan adanya media ini dapat memberikan layanan informasi sebagai media edukasi dalam memberikan pemahaman terhadap kesadaran masyarakat mengatasi permasalahan sampah. Perubahan dan perkembangan teknologi yang sangat cepat dewasa ini memerlukan dukungan dalam bentuk pembelajaran dan penciptaan baru yang berkelanjutan dari berbagai ide dan keterampilan. Perubahan dan perkembangan ini, berdampak pada kehidupan manusia di segala bidang, salah satunya yaitu bidang pendidikan (Arianti, ddk., 2020). Perkembangan ilmu pengetahuan dan teknologi telah mendorong teknologi pendidikan untuk ikut berkembang. Perkembangan tersebut telah mengilhami penemuan beberapa alat komunikasi dan teknologi untuk meningkatkan perkembangan informasi secara masal dan cepat. Selain itu Perkembangan ilmu pengetahuan dan teknologi yang sangat pesat memberikan dampak pada perkembangan media pembelajaran. Aplikasi media pembelajaran dibidang pendidikan melahirkan banyak terobosan baru dalam meningkatkan efisiensi dan efektifitas proses pembelajaran. Salah satunya adalah melalui layanan informasi berbasis smartphone (telepon pintar) (Hakky, Wirasasmita, Uska, 2018).

Layanan informasi membantu memaksimalkan dalam menyampaikan informasi kepada masyarakat salah satunya smartphone (telepon pintar). Di kehidupan saat ini yang memerlukan mobilitas tinggi, penggunaan smartphone menjadi sangat penting, tidak hanya berfungsi sebagai alat komunikasi smartphone juga mempunyai fungsi sebagai alat untuk menyampaikan 
dan menerima informasi. Berdasarkan data Badan Pusat Statistik (BPS) selama periode 20102018 peningkatan persentase penduduk yang telah memiliki/menguasai telepon seluler sebesar 3,05 persen per tahun, berdasarkan klasifikasi daerah, perdesaan lebih besar rata-rata pertumbuhan penduduk yang memiliki telepon seluler yaitu 3,36 persen sedangkan perkotaan 2,53 persen (Sutarsih, dkk., 2018).

Smartphone sekarang ini bukan hanya untuk mempermudah mencari informasi tetapi sebenarnya banyak sisi positif dan negatifnya, baik dari segi berkomunikasi, segi kesehatan, segi budaya, segi sosial, dan segi ekonomi (Marpaung, 2018). Namun dalam pemanfaatannya di masyarakat smartphone sering kali tidak efektif lebih dominan kepada game dan sosial media. Oleh karena itu agar pemanfaatan smartphone lebih maksimal dan memperoleh ilmu pengetahuan perlu adanya media edukasi yang dapat di akses melalui smartphone yakni media edukasi sampah berbasis android, media ini berisi tentang materi sampah dan penanganannya serta materi pengolahan sampah sehingga bernilai ekonomis.

Penelitian yang sudah dilakukan sebelumnya tentang pemberdayaan masyarakat melalui pengolahan sampah skala rumah tangga dalam meningkatkan pengetahuan dan keterampilan masyarakat, metode yang paling tepat digunakan untuk edukasi dan pelatihan adalah metode ceramah dan demonstrasi langsung (Dewi, Sumarjan, Jannah, 2020). Hasil yang didapatkan yaitu terbentuknya komitmen bersama untuk mewujudkan lingkungan zero waste dan peserta mendapatkan pemahaman yang baik tentang pengelolaan sampah plastik serta meningkatkan kesadaran untuk memilah dan membuang sampah pada tempat yang sesuai dengan jenisnya (Rahmawati, dkk., 2020).

Desa Tembeng Putik merupakan desa yang terletak di kabupaten Lombok Timur, yang mata pencarian utama dari warganya yaitu petani dan penambang pasir. Penambangan pasir menjadi isu utama lingkungan di Tembeng Putik. Selain itu berdasarkan hasil observasi awal kesadaran akan kebersihan lingkungan warga masih rendah, dapat dilihat dari sampah yang menumpuk di pinggir jalan utama desa. Semua sampah tercampu, dari sampah rumah tangga, sampah alam, dan sampah plastik. Hal ini diakibatkan karena kurangnya pengetahuan warga tentang pemilahan dan pengolahan sampah yang baik.

Berdasarkan uraian di atas, program pengabdian ini bertujuan untuk mengedukasi masyarakat mengenai pentingnya lingkungan Zero Waste dan untuk melatih masyarakat Tembeng Putik dalam mengelola atau mendaur ulang sampah menjadi barang yang lebih bermanfaat.

\section{METODE PELAKSANAAN}

\section{Waktu dan tempat}

Kegiatan pengabdian masyarakat yang dilakukan dari 18 - 28 Oktober 2019 di Dusun Lengkok Lendang desa Tembeng Putik Kabupaten Lombok Timur. Sosialiasi zero waste menggunakan aplikasi android dilakukan dengan mendemonstrasikan kepada masyarakat terkait cara instalasi aplikasi android dan cara penggunaan aplikasi android zero waste tersebut sedangkan pelatihan pembuatan bunga platistik bekerjsama dengan Bunga Sampah Lestari (BSL) secara langsung mendemonstrasikan cara memanfaatkan sampah plastik untuk membuat bunga plastik sebagai produk yang dihasilkan

\section{Prosedur pelaksanaan}


Tahapan - tahapan pelaksaan yang dilakukan pada kegiatan pengabdian kepada masyarakat yang dilakukan di Dusun Lengkok Lendang Desa Tembeng Putik Kabupaten Lombok Timur dimulai dari bulan 18 - 30 Oktober 2019 Kegiatan PPM ini melibatkan dosen di lingkungan Fakultas Matematika dan Ilmu Pengetahuan Alam (FMIPA) dan Himpunan Mahasiswa Program Studi (HMPS) Pendidikan Informatika Universitas Hamzanwadi. Agar kegiatan PPM ini dapat berjalan dengan baik, maka metode yang digunakan pada pelaksanaan kegiatan PPM ini yaitu :

1. Metode Demonstrasi

Pada tahapan ini, dilakukan dengan mendemonstasikan aplikasi yang sudah dikembangkan kepada siswa, setalah itu siswa pempraktikkan cara menginstal aplikasi edukasi zero waste, serta mencoba mengoperasikan aplikasi zero waste dengan mencoba melihat materi yang terdapat pada aplikasi android zero waste, setalah siswa berhasil mempraktikkan cara instalasi aplikasi dan mempelajari materi yang terdapat pada aplikasi zero waste, setalah itu harapannya siswa yang sudah mengikuti kegiatan sosialisasi penggunaan dan pengoperasian aplikasi, juga dapat mensosialisasikan media edukasi ini mulai dari keluarga, tetangga dan masyarakat sekitarnya.

2. Metode Praktik

Pada tahapan ini, dilakukan pelatihan secara langsung kepada siswa dan masyarakat sekitar di dusun lengkok lendang desa tembeng putik kabupaten lombok timur dengan bekerja sama dengan Bunga Sampah Lestari (BSL), mahasiswa pendidikan informatika berbsama - sama mempraktikan secara langsung cara membuat produk rumah tangga dari sampah plastik sebagai contoh bunga plastik.

3. Metode Obsevasi

Pada tahapan ini, dilakukan observasi kegiatan PPM secara langsung untuk pengambilan data hasil pelaksanaan kegiatan PPM selama kegiatan PPM berlangsung. Hasil pelaksanaan kegiatan PPM selanjutnya dikumpulkan dan selanjutnya hasil tersebut disusun menjadi laporan akhir kegiatan (Sukmadinata, 2017).

\section{HASIL DAN PEMBAHASAN}

\section{Hasil}

Dari hasil pelaksanaan pengabdian kepada masyarakat yang dilakukan di dusun lengkok lendang desa Tembeng Putik tepatnya di SMK NW Tembeng Putik diperoleh hasil seperti terlihat pada tabel 1. Uraian Hasil Pelaksanan Edukasi Zero Waste berikut ini:

Tabel 1. Uraian Hasil Pelaksanaan Kegaitan PPM

\begin{tabular}{cllll}
\hline No. & Hari, Tanggal & \multicolumn{1}{c}{ Kegiatan } & \multicolumn{1}{c}{ Peserta } & \multicolumn{1}{c}{ Hasil } \\
\hline $\mathbf{1}$ & $\begin{array}{l}\text { Jumat, } \\
\text { 18 Oktober 2019 }\end{array}$ & $\begin{array}{l}\text { Rapat sosialisasi dan } \\
\text { koordinasi program }\end{array}$ & $\begin{array}{l}\text { Dosen dan } \\
\text { mahasiswa }\end{array}$ & $\begin{array}{l}\text { - Terbentuknya kesepakatan } \\
\text { program pelaksanaan kegiatan } \\
\text { - Terbentuknya panitia pelaksana } \\
\text { kegiatan }\end{array}$ \\
\hline $\mathbf{2}$ & $\begin{array}{l}\text { Sabtu, } \\
19 \text { Oktober 2019 }\end{array}$ & $\begin{array}{l}\text { Rapat kerja } \\
\text { penyusunan program } \\
\text { kegiatan }\end{array}$ & $\begin{array}{l}\text { Dosen dan } \\
\text { mahasiswa }\end{array}$ & $\begin{array}{l}\text { - Terbentuknya jadwal pelaksanaan } \\
\text { kegiatan }\end{array}$ \\
& & & $\begin{array}{l}\text { - Pembagian tugas panitia pelaksana } \\
\text { kegiatan }\end{array}$ \\
\hline
\end{tabular}


Wirasasmita, R. H., Arianti, B. D. D., Uska, M. Z., Kholisho, Y. N., \& Wardi, Z. (2020). Edukasi zero waste berbasis empati (menggunakan teknologi informasi berbasis android). ABSYARA: Jurnal Pengabdian Pada Masyarakat, 1(2), 1-8. doi:10.29408/ab.v1i2.2749

\begin{tabular}{|c|c|c|c|c|}
\hline & & & & $\begin{array}{l}\text { - Tersusunnya biaya dan daftar } \\
\text { sarana dan prasarana kegiatan }\end{array}$ \\
\hline 3 & $\begin{array}{l}\text { Minggu, } \\
20 \text { Oktober } 2019\end{array}$ & $\begin{array}{l}\text { Pembuatan Proposal, } \\
\text { surat perizinan }\end{array}$ & Mahasiswa & $\begin{array}{l}\text { - Proposal kegiatan } \\
\text { - Surat-surat perizinan }\end{array}$ \\
\hline 4 & $\begin{array}{l}\text { Senin, } \\
21 \text { Oktober }\end{array}$ & $\begin{array}{l}\text { Mengurus perizinan } \\
\text { di lokasi pelaksanaan } \\
\text { kegiatan } \\
\text { Menghubungi mitra }\end{array}$ & $\begin{array}{l}\text { Dosen dan } \\
\text { mahasiswa }\end{array}$ & $\begin{array}{l}\text { - Mendapatkan izin pelaksanaan } \\
\text { kegiatan dari perangkat desa } \\
\text { Tembeng Putik } \\
\text { - Mendapat kesepakatan dengan } \\
\text { mitra yaitu komunitas Bunga } \\
\text { Sampah Lestari (BSL) }\end{array}$ \\
\hline 5 & $\begin{array}{l}\text { Selasa - Kamis, } \\
22-24 \text { Oktober } \\
2019\end{array}$ & $\begin{array}{l}\text { Persiapan pelaksanaan } \\
\text { kegiatan }\end{array}$ & $\begin{array}{l}\text { Dosen dan } \\
\text { mahasiswa }\end{array}$ & $\begin{array}{l}\text { - Dana pelaksanaan kegiatan berasal } \\
\text { dari lembaga dan dosen } \\
\text { - Sarana dan prasarana seperti: alat } \\
\text { transportasi, alat masak, kuota } \\
\text { internet, dan lain-lain }\end{array}$ \\
\hline 6 & $\begin{array}{l}\text { Jumat, } \\
25 \text { Oktober } 2019\end{array}$ & $\begin{array}{l}\text { Berangkat ke lokasi } \\
\text { pelaksanaan program }\end{array}$ & $\begin{array}{l}\text { Dosen dan } \\
\text { mahasiswa }\end{array}$ & $\begin{array}{l}\text { - Tiba di lokasi pelaksanaan } \\
\text { program } \\
\text { - Acara penyambutan oleh pihak } \\
\text { desa }\end{array}$ \\
\hline 7 & $\begin{array}{l}\text { Sabtu, } \\
26 \text { Oktober } 2019\end{array}$ & $\begin{array}{l}\text { Pelaksanaan kegiatan } \\
\text { edukasi program } \\
\text { lingkungan Zero } \\
\text { Waste menggunakan } \\
\text { aplikasi Zero Waste } \\
\text { Diskusi mengenai } \\
\text { lingkungan zero waste }\end{array}$ & $\begin{array}{l}\text { Dosen, } \\
\text { mahsiswa, } \\
\text { dan warga }\end{array}$ & $\begin{array}{l}\text { - Warga dapat mendownload, } \\
\text { menginstal dan menggunakan } \\
\text { aplikasi Zero Waste } \\
\text { - Warga mendapat pengetahuan } \\
\text { tentang lingkungan zero waste } \\
\text { melalui aplikasi tersebut }\end{array}$ \\
\hline 8 & $\begin{array}{l}\text { Minggu, } \\
27 \text { Oktober } 2019\end{array}$ & $\begin{array}{l}\text { Pelaksanaan pelatihan } \\
\text { pemanfaatan sampah } \\
\text { (daur ulang) menjadi } \\
\text { barang yang lebih } \\
\text { bermanfaat }\end{array}$ & $\begin{array}{l}\text { Dosen, } \\
\text { mahasiswa, } \\
\text { mitra (BSL) } \\
\text { dan warga }\end{array}$ & $\begin{array}{l}\text { - Warga mampu membuat bunga } \\
\text { dari botol dan gelas plastik bekas }\end{array}$ \\
\hline 9 & $\begin{array}{l}\text { Senin, } \\
27 \text { Oktober } 2019\end{array}$ & $\begin{array}{l}\text { Pentutupan acara } \\
\text { kegiatan PPM }\end{array}$ & $\begin{array}{l}\text { Dosen, } \\
\text { mahasiswa } \\
\text { dan warga }\end{array}$ & $\begin{array}{l}\text { - Pihak desa mengharapkan } \\
\text { kedepannya kegiatan ini dapat } \\
\text { terus dilakukan }\end{array}$ \\
\hline 10 & $\begin{array}{l}\text { Selasa - Rabu, } \\
28-29 \text { Oktober } \\
2019\end{array}$ & Penyusunan Laporan & $\begin{array}{l}\text { Dosen dan } \\
\text { mahasiswa }\end{array}$ & - Laporan pelaksanaan kegiatan \\
\hline
\end{tabular}



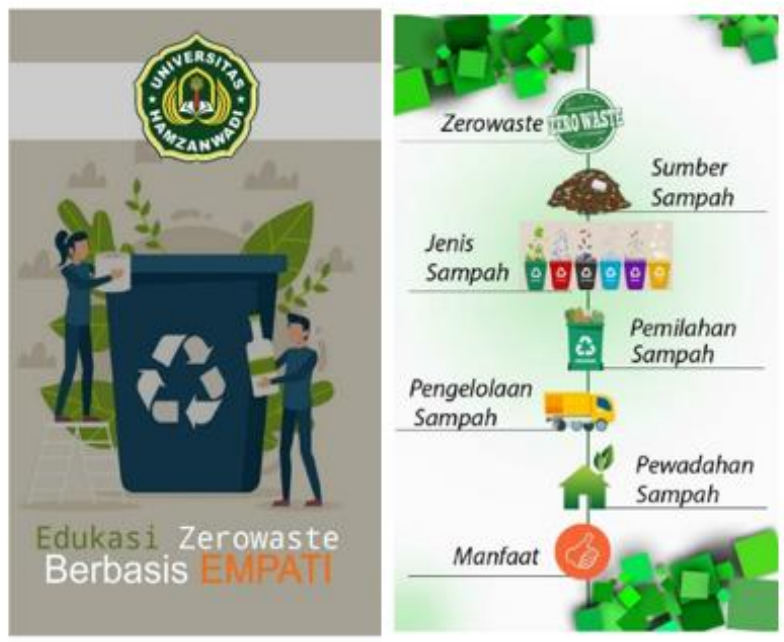

Gambar 1. Aplikasi Zero Waste

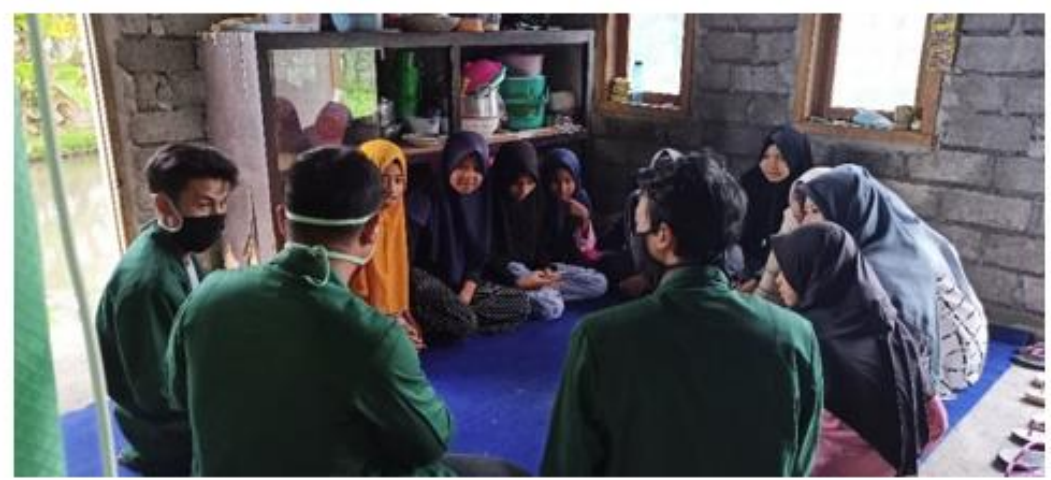

Gambar 2. Sosialisasi penggunaan aplikasi zero waste berbasis android

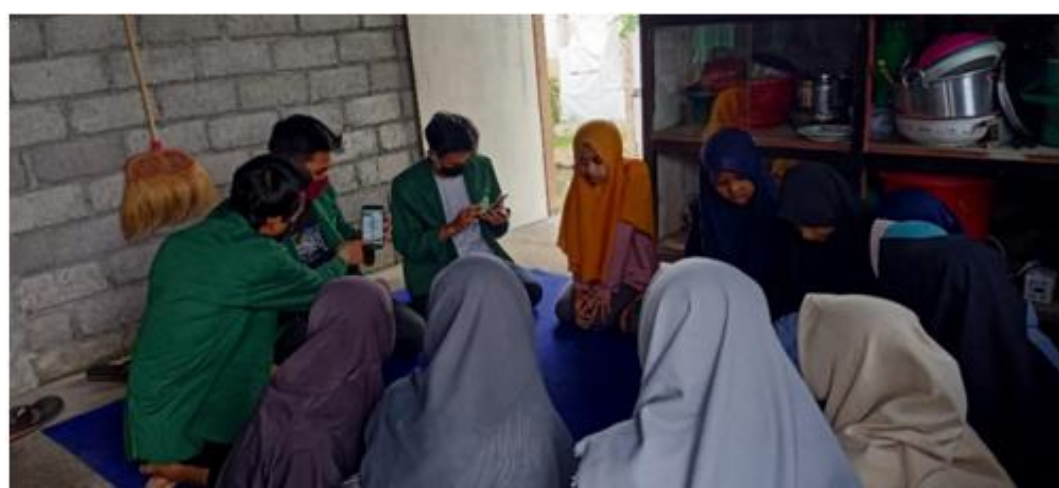

Gambar 3. Sosialisasi materi edukasi zero waste 


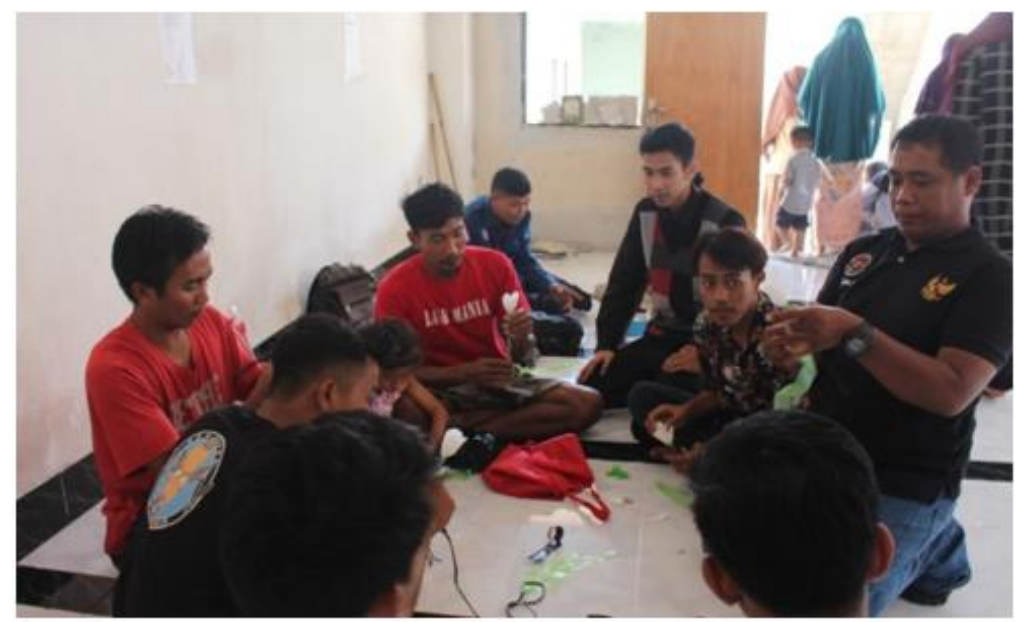

Gambar 4. Pelatihan membuat bunga plastik dari botol plastik bekas oleh pihak BSL

\section{Pembahasan}

Pada tahap edukasi program lingkungan zero waste menggunakan aplikasi zero waste ditemukan bahwa masih banyak masyarakat yang belum mengetahui apa itu program zero waste, padahal program ini merupakan program dari pemerintah provinsi NTB. Sehingga diadakan diskusi dengan warga untuk memperkenalkan program lingkungan zero waste tersebut. Setelah itu baru diperkenalkan aplikasi zero waste yang digunakan. Warga diedukasi cara menggunakan aplikasi tersebut, dari cara mendownload, menginstal, sampai menggunakan aplikasi Zero Waste. Selain itu warga juga diajarkan cara memilah dan memilih sampah-sampah yang ada disekitar, sehingga warga dapat memisahkan sampah berdasarkan jenis dan kegunaannya.

Untuk tahap pelatihan membuat bunga dari barang bekas seperti botol plastik bekas, gelas plastik bekas dan lain-lain. Narasumber kegiatan ini berasal dari mitra yaitu komunitas Bunga Sampah Lesatari (BSL) lombok. Dalam kegiatan ini antuasias warga sangat tinggi, peserta kegaitan lebih banyak dari pada hari pertama. Warga merasa senang dengan kegiatan ini. Banyak warga yang membawa botol plastik bekas dari rumah mereka. Warga berharap kedepannya melalui kegiatan ini warga mampu mencari alternatif usaha untuk dapat pemasukan tambahan selain menjadi penambang pasir. Selain itu dari pihak perangkat desa mengharapkan kegiatan PPM ini bisa berlangsung setiap tahunnya dengan program yang berbeda.

\section{SIMPULAN}

Dengan adanya aplikasi Zero Waste yang telah disosialisasikan kepada warga dapat membantu warga untuk lebih meningkatkan kesadaran atas pentingnya lingkungan zero waste di kehidupan. Warga Tembeng Putik sudah memiliki pengetahuan tentang lingkunga zero waste dan cara pemilihan sampah yang benar. Selanjutnya kedepanya diharapkan warga dapat menerapkan pengetahuan tersebut di kehidupan sehari-hari. Pelatihan pemanfaatan barang bekas (sampah botol plastik) menjadi bunga menambah alternatif penghasilan warga jika dimanfaatkan dan dikelola dengan profesional. Hal ini bisa dilakukan apabila perangkat desa juga mendukung atau memprogramkan kegiatan ini sebagai promosi desa, sehingga mata pencarian warga yang tadinya sebagai penambang pasir bisa tergantikan oleh pembuat 
kerajinan dari pelastik bekas. Jika hal ini bisa terwujud maka penambangan pasir akan berkurang, sehingga kerusakan lingkungan juga bisa diminimalisir.

\section{PERNYATAAN PENULIS}

Artikel ini belum pernah dipublikasikan dalam jurnal apapun.

\section{DAFTAR PUSTAKA}

Arianti, B. D. D., Kholisho, Y. N., Ismatulloh, K., Wirasamita, R. H., Uska, M. Z., Fathoni A., Jamaluddin. (2020). Pelatihan computer based test (cbt) ujian nasional untuk siswa smk di lombok timur. ABSYARA: Jurnal Pengabdian Pada Masyarakat, 1(1), 22-23.

Dewi, I. N., Royani, I., Sumarjan, S., \& Jannah, H. (2020). Pemberdayaan masyarakat melalui pengelolaan sampah skala rumah tangga menggunakan metode komposting. Sasambo: Jurnal Abdimas (Journal of Community Service), 2(1), 12-18

Hakky, M. K., Wirasasmita, R. H., Uska M. Z., (2018). Pengembangan media pembelajaran berbasis android untuk siswa kelas $\mathrm{x}$ pada mata pelajaran sistem operasi. Jurnal Edumatic, 2(1), 24-33. DOI : 10.29408/edumatic.v2i1.868

Intan, T., Rijati, S.,(2019). Kampanye zero waste sebagai gaya hidup pada mahasiswa dan ibu rumah tangga di jatinangor (analisis situasional dan rencana solusi). Jurnal Dayamas, $4(1), 5-13$

NTB. (2019). Peraturan Gubernur Nusa Tenggara Barat Nomor 44 Tahun 2019 Tentang Program Strategis dan Unggulan Daerah dalam Pencapaian Indikator Kinerja Utama Pemerintah Provinsi Nusa Tenggara Barat Tahun 2019-2023.

Marpaung, J. (2018). Pengaruh penggunaan gadget dalam kehidupan (the effect of use of gadget in life). Jurnal KOPASTA, 5(2), 55-64.

Rahmawati, C., Nopitasari, B. L., Mardiyah WD, S., Wardani, A. K., \& Nurbaety, B. (2020). Penyuluhan pengelolaan sampah plastik menuju "Zero Waste kampus ummat." SELAPARANG Jurnal Pengabdian Masyarakat Berkemajuan, 3(2), 196-198

Sukmadinata, N. S. (2017). Metode Penelitian Pendidikan. PT. Remaja Rosdakarya.

Sutarsih, T., Rozama, N. A., Untari, R., Siswayu, G., \& Maharani, K. (2018). Statistik Telekomunikasi Indonesia. Badan Pusat Statistik.

Widiarti, I. W. (2012). Pengelolaan Sampah Berbasis "Zero Waste" Skala Rumah Tangga Secara Mandiri. Jurnal Sains \& Teknologi Lingkungan, 4(2), 107-145

Zulkifli, M., Ayub, A. F., \& Shery, M. (2019). Statistik Sumber Daya Laut dan Pesisir Sampah Laut Indonesia (A. Apriyanto \& N. Supriyani (ed.)). Badan Pusat Statistik/BPS-Statistics Indonesia. 